\title{
Kepastian Hukum Penyelesaian Sengketa Utang Piutang Berdasarkan Perjanjian Jual Beli yang Terindikasi Tindak Pidana Melalui Lembaga Kepailitan
}

\author{
Jeffrey Thomas Lubis, Elisatris Gultom, Somawijaya \\ Fakultas Hukum Universitas Padjadjaran, Bandung, Indonesia \\ Email: thomasjeffreylubis@gmail.com; elisatris68@gmail.com; soma_unpad@yahoo.co.id
}

\begin{abstract}
ABSTRAK
Lalu lintas dunia bisnis dalam era ini banyak melahirkan hubungan-hubungan hukum terkhususnya dalam lapangan jual beli. Hubungan hukum yang lahir atas perjanjian jual beli ini tidak selamanya berjalan dengan mulus, kadangkala adanya salah satu pihak yang tidak melakukan kewajiban atau prestasinya, baik itu penjual maupun pembeli. Pihak penjual berkewajiban untuk memberikan barang yang telah disepakati dan melakukan levering, sedangkan pihak pembeli berkewajiban untuk membayarkan sejumlah uang yang telah disepakati terhadap objek jual belinya. Keadaan salah satu pihak tidak melaksanakan kewajiban atau prestasinya dikenal dengan wanprestasi. Sengketa wanprestasi dalam hukum perdata bisa diselesaikan dengan beberapa jalur, seperti gugatan perdata biasa bahkan kepailitan sebagai ultimum remedium dalam penyelesaian sengketa utang piutang. Namun, pada praktiknya terkadang masih banyak masyarakat yang masih belum dapat membedakan antara wanprestasi dengan penipuan dalam ranah hukum pidana. Sehingga, kerap terjadi perkara kepailitan dan perkara pidana yang dijalankan bersamaan yang pada akhirnya akan berakibat pada permasalahan sita umum yang diatur dalam Undang-Undang Nomor 37 Tahun 2004 tentang Kepailitan dan Penundaan Kewajiban Pembayaran Utang (selanjutnya disebut "UU KPKPU") dan sita pidana yang diatur dalam Kitab Undang-Undang Hukum Acara Pidana. Dengan demikian, penelitian ini akan dimaksudkan untuk mempertegas kepastian hukum pengertian utang yang dimaksud dalam Pasal 2 ayat (1) jo. 8 ayat (4) UU KPKPU dan kepastian hukum penyelesaian sengketa utang piutang yang terindikasi tindak pidana melalui lembaga kepailitan. Penelitian ini ditulis dengan metode pendekatan penelitian yuridis normatif untuk mengelaborasikan asas dan teori hukum dengan praktik yang ada di lapangan yang bersifat desktiptif analitis yang didasarkan pada peraturan perundang-undangan dan dikaitkan dengan kebiasaan dalam das sollen dan das sein. Sehingga, masyarakat para pencari keadilan dapat menemukan kepastian hukum mengenai pengertian utang dalam UU KPKPU serta langkah yang lebih tepat dalam penyelesaian sengketa utang piutang yang terindikasi tindak pidana.
\end{abstract}

Kata Kunci: Jual Beli, Kepailitan, Sengketa Utang Piutang, Tindak Pidana.

\section{PENDAHULUAN}

Perkembangan era globalisasi sangat mempengaruhi segala bidang kehidupan, khususnya ekonomi dan bisnis. Perekonomian yang semakin berkembang tidak menutup kemungkinan akan timbulnya sengketa dalam dunia bisnis khususnya sengketa utang piutang. UU KPKPU muncul sebagai implementasi dari semangat negara untuk melakukan pembangungan hukum nasional dalam penyelesaian sengketa utang piutang dengan tetap mengarah kepada Pancasila dan UUD 1945. 
Semangat penyelesaian sengketa utang piutang dalam UU KPKPU merupakan perwujudan dari Pasal 33 ayat (4) UUD 1945. Ketentuan pasal ini mencerminkan semangat pembangunan nasional didasarkan pada asas demokrasi ekonomi (Arif Firmansyah, 2012, p. 283) demi mewujudkan cita-cita Negara dalam menciptakan keadilan sosial bagi seluruh rakyat Indonesia (Elli Ruslina, 2012, p. 50).

Kepailitan merupakan salah satu lembaga penyelesaian sengketa utang piutang di Indonesia ketika debitor sudah tidak mau atau tidak mampu lagi untuk membayar utangutangnya kepada para kreditornya (H. M. N. Purwosutjipto, 1979, p. 28). Sebagai implementasi dari Pasal 1131 dan Pasal 1132 KUHPerdata, lembaga kepailitan memiliki tujuan untuk menjamin pelunasan yang proporsional kepada para kreditor dari debitor pailit serta melindungi debitor maupun kreditor dari pihak-pihak yang beriktikad buruk (Sutan Remy Sjahdeini, 2009, p. 28).

Kepailitan menurut UU KPKPU merupakan sita umum atas seluruh harta kekayaan Debitor Pailit yang mana Kurator diberikan wewenang pengurusan dan pemberesan harta pailit di bawah pengawasan Hakim Pengawas (Man S. Sastrawidjadja, 2006, p. 91). Syarat untuk mengajukan permohonan pernyataan pailit tercantum dalam Pasal 2 ayat (1) jo. 8 ayat (4) UU KPKPU yang pada pokoknya mensyaratkan adanya 2 (dua) atau lebih kreditor dan tidak membayarnya sedikitnya 1 (satu) utang yang telah jatuh waktu dan dapat ditagih serta utang harus dapat dibuktikan secara sederhana.

Definisi utang yang dimaksud dalam Pasal 1 angka 6 UU KPKPU merupakan definisi utang dalam pengertian yang luas. Utang dalam pengertian yang luas memiliki arti bahwa utang bukan saja utang yang lahir berdasarkan perjanjian utang piutang saja, tetapi meliputi seluruh kewajiban yang timbul dari suatu perjanjian menyangkut prestasi yang dilakukan oleh pihak dalam perjanjian (Sutan Remy Sjahdeini, 2009, p. 76).

Pengertian utang dalam UU KPKPU tersebut merupakan implementasi utang yang dianut dalam Buku II KUHPerdata tentang Perikatan. Pasal 1234 KUHPerdata menyatakan objek dalam suatu perikatan merupakan prestasi yang berbentuk untuk memberikan sesuatu, untuk berbuat sesuatu dan untuk tidak berbuat sesuatu (Mariam Darus Badrulzaman, 2011, p. 11).

Perjanjian jual beli lahir ketika telah terjadi kesepakatan antara para pihak mengenai objek jual beli termasuk harga dari objek jual beli tersebut, maupun harganya belum dibayarkan (Subekti, 1995, p. 2). Kewajiban atau prestasi dari pembeli adalah untuk memberikan sesuatu dalam bentuk membayarkan harga yang telah disepakati. Sedangkan kewajiban atau prestasi dari penjual adalah untuk memberikan sesuatu yaitu objek jual beli yang telah disepakati.

Namun, das sollen tidak selalu berjalan seiringan dengan das sein. Adakalanya salah satu pihak dalam perjanjian tidak melaksanakan prestasinya atau biasa disebut wanprestasi. Wanprestasi merupakan keadaan dimana debitor telah tidak memenuhi kewajiban prestasinya dengan baik dan debitor memiliki unsur kesalahan terhadapnya (J. Satrio, 2014, p. 3).

Pada praktiknya masih banyak yang belum dapat membedakan wanprestasi dengan tindak pidana penipuan dan memang dalam hal ini antara keduanya memiliki banyak persinggungan. Namun sebenarnya dapat ditemukan perbedaan yang mendasar diantara keduanya yaitu dapat terlihat dari adanya niat (mens rea) dari pelaku (Sugirhot Marbun, 2015, p. 134).

Irisan antar keduanya ini menimbulkan permasalahan terhadap langkah penyelesaiannya. Lembaga kepailitan dan pidana yang sama-sama merupakan ultimum remedium atau senjata pamungkas terakhir akan berakibat pada kepentingan rezim hukum mana yang akan didahulukan. Terlebih lagi, keduanya memiliki akibat hukum terhadap penyitaan yang terjadi, dimana dalam kepailitan akan melahirkan sita umum terhadap seluruh 
harta kekayaan debitor dan dalam penyelesaian perkara pidana akan melahirkan sita pidana untuk kepentingan penyidikan, penuntutan maupun pembuktian.

Seperti contohnya dalam kasus PT Aku Digital Indonesia atau Akumobil yang dimohonkan pailit oleh para kreditornya dan di satu sisi Akumobil juga telah diamankan oleh pihak Kepolisian dari Polrestabes Bandung dengan dugaan tindak pidana penipuan dan tindak pidana penggelapan. Namun, Putusan Pengadilan Niaga Pada Pengadilan Negeri Jakarta Pusat Nomor 56/Pdt.Sus-Pailit/2019/PN Niaga Jkt Pst. yang memeriksa permohonan pernyataan pailit terhadap Akumobil menolak permohonan pernyataan pailit dengan pertimbangan hukum yang pada pokoknya menolak permohonan pernyataan pailit dikarenakan terdapat utang namun belum jatuh tempo sebagaimana dinyatakan dalam Pasal 2 ayat (1) UU KPKPU serta dikarenakan ada unsur pidana di dalamnya, maka pembuktian menjadi tidak sederhana.

Dengan demikian, telah timbul suatu ketidakpastian hukum mengenai pemaknaan utang yang dimaksud dalam Pasal 2 ayat (1) UU KPKPU serta langkah penyelesaian sengketa utang piutang yang terindikasi tindak pidana melalui lembaga kepailitan. Sehingga tulisan ini akan mencoba menjelaskan kedua persoalan tersebut.

\section{METODE PENELITIAN}

Penelitian ini ditulis dengan menggunakan metode penelitian normatif yang merupakan suatu metode penelitian hukum dengan cara melakukan penelitian pada studi kepustakaan baik data primer maupun data sekunder. Metode pendekatan yang digunakan adalah metode pendekatan yuridis normatif untuk mengelaborasikan asas dan teori hukum dengan praktik yang ada di lapangan yang bersifat desktiptif analitis yang didasarkan pada peraturan perundang-undangan dan dikaitkan dengan kebiasaan dalam das sollen dan das sein (Soerjono Soekanto dan Sri Mamudji, 2003, p. 1). Metode analisis data yang akan penulis gunakan juga adalah metode normatif kualitatif yang dilakukan dengan meneliti asas-asas dan norma-norma hukum yang berpangkal dari peraturan-peraturan yang ada sehingga seluruh data hasil penelitian dapat menjadi jawaban atas permasalahan yang ada dalam penyelesaian sengketa utang piutang berdasarkan perjanjian jual beli yang terindikasi tindak pidana melalui lembaga kepailitan.

\section{HASIL DAN PEMBAHASAN}

\section{Kepastian Hukum Utang dalam Permohonan Pernyataan Pailit Debitor Berdasarkan Perjanjian Jual Beli Terhadap Prestasi untuk Memberikan Sesuatu}

Dalam lalu lintas dunia bisnis terutama dalam hal terjadinya jual beli, antara penjual dan pembeli memiliki kewajiban yang perlu dipenuhi satu sama lain. Penjual berkewajiban untuk memberikan barang serta melakukan penyerahan dan pembeli berkewajiban untuk melakukan pembayaran sesuai harga yang telah disepakati. Kewajiban yang dimiliki para pihak dalam jual beli ini dalam KUHPerdata diistilahkan sebagai prestasi.

Pasal 1234 KUHPerdata membagi prestasi menjadi 3 (tiga) bentuk yaitu untuk memberikan sesuatu, untuk melakukan sesuatu dan untuk tidak melakukan sesuatu. Ketika salah satu pihak dalam perjanjian terutama perjanjian jual beli tidak mengindahkan kewajibannya untuk berprestasi, maka pihak tersebut dapat dianggap wanprestasi. Dengan adanya keadaan wanprestasi, maka telah timbul utang yang dipersamakan dengan kewajiban seseorang untuk memenuhi prestasinya yang lahir karena perjanjian (Subekti, 1995, p. 1).

Perkara wanprestasi pada umumnya akan diselesaikan melalui Pengadilan Negeri. Namun, suatu perkara wanprestasi yang tidak dapat diselesaikan di Pengadilan Negeri biasanya akan dibawa lebih jauh untuk diselesaikan di Pengadilan Niaga pada Pengadilan Negeri melalui 
permohonan pernyataan pailit terlebih jika si debitor melakukan wanprestasi kepada lebih dari satu kreditor. Hal ini tercermin pada salah satu contoh kasus yaitu kasus dari PT Akumobil.

PT Akumobil telah melakukan wanprestasi terhadap perjanjian jual beli mobil, dimana PT Akumobil sebagai penjual mobil telah tidak melaksanakan kewajibannya sebagai penjual untuk menyerahkan barangnya yaitu mobil setelah harga mobilnya telah disepakati dan telah dibayarkan oleh pihak pembeli. PT Akumobil juga menjanjikan refund jika mobil tidak kunjung diserahkan selama jangka waktu 14 (empat belas) hari. PT Akumobil melakukan wanprestasi tidak hanya kepada satu pembelinya, tetapi sampai ribuan pembelinya. Sehingga, dengan memperhatikan tujuan dari kepailitan itu sendiri PT Akumobil dimohonkan pailit oleh beberapa kreditornya.

Permohonan pailit diajukan atas dasar PT Akumobil telah tidak melaksanakan kewajibannya padahal telah dilakukan mediasi dengan pihak Kepolisian Kota Bandung yang melahirkan adanya rescheduling yang dimintakan oleh PT Akumobil. Namun, permohonan pernyataan pailit yang diajukan oleh kreditor dari PT Akumobil ini ditolak oleh Pengadilan Niaga pada Pengadilan Negeri Jakarta Pusat dengan alasan bahwa utang belum jatuh waktu.

Berdasarkan kasus tersebut, terdapat suatu ketidakpastian hukum mengenai syarat pengajuan permohonan pernyataan pailit mengenai syarat utang itu sendiri. Utang telah jatuh waktu dalam UU KPKPU dimaknai sebagai utang yang timbul akibat telah lampaunya waktu penjadwalan yang telah ditentukan dalam perjanjian (Sutan Remy Sjahdeini, 2009, 57). Dengan lampaunya waktu penjadwalan, debitor telah dapat dikatakan wanprestasi dan timbul kewajiban untuk melaksanakan prestasi dalam perjanjiannya sehingga lahir utang yang telah jatuh waktu.

Perbuatan PT Akumobil untuk tidak melakukan penyerahan mobil terhadap para pembelinya dan tidak mengindahkan klausul refund yang harus dilakukannya setelah jangka waktu 14 (empat belas) hari setelah perjanjian dibuat yang dimintakan pembelinya serta tidak mengindahkan putusan mediasi yang dilakukan oleh PT Akumobil dengan para pembelinya, melahirkan utang yang telah jatuh waktu terhadap PT Akumobil karena telah lampaunya waktu penjadwalan yang telah menjadi kewajibannya untuk berprestasi.

PT Akumobil telah masuk ke dalam salah satu jenis dari wanprestasi yaitu tidak melakukan prestasi sesuai dengan Pasal 1243 KUHPerdata karena PT Akumobil senyatanya telah tidak melaksanakan prestasinya untuk memberikan sesuatu. Terdapat unsur salah yang telah dilakukan oleh PT Akumobil yaitu tidak melaksanakan prestasinya untuk memberikan mobil kepada pembeli mobilnya, sehingga senyatanya telah jelas bahwa PT Akumobil telah melakukan wanprestasi.

Keadaan wanprestasi debitor dalam permohonan pernyataan pailit senyatanya telah memenuhi unsur Pasal 2 ayat (1) jo. 8 ayat (4) UU KPKPU. Wanprestasi melahirkan utang yang harus dipenuhi oleh debitor. Salah satu unsur utang yang dimaksud dalam Pasal 1 angka 6 UU KPKPU adalah utang yang timbul karena perjanjian. Sebagaimana utang yang timbul akibat wanprestasi merupakan utang yang timbul akibat perjanjian.

Secara umum, kewajiban debitor untuk berprestasi terutama prestasi untuk memberikan sesuatu atau biasa dikenal dengan pembayaran tidak selamanya hanya berupa memberikan sejumlah uang namun juga termasuk memberikan suatu kenikmatan (J. Satrio 2001, p. 13). Kewajiban para pihak untuk berprestasi menurut Subekti dapat dipersamakan dengan utang yang dimaksud dalam KUHPerdata (Subekti, 1985, p. 122-123). Utang lahir baik karena perjanjian maupun perbuatan melawan hukum.

Sehingga, keadaan wanprestasi dimana debitor tidak melaksanakan prestasinya untuk memberikan sesuatu juga dapat dipersamakan dengan utang karena telah tidak melaksanakan kewajiban dalam perjanjiannya. Terlebih dalam suatu perjanjian jual beli, dimana terkadang 
timbul keadaan pembeli telah melaksanakan prestasinya yaitu melakukan pembayaran sesuai harga yang telah disepakati, namun penjual tidak melaksanakan prestasinya untuk memberikan sesuatu yaitu memberikan objek jual belinya.

Keadaan yang demikian dapat dikategorikan ke dalam keadaan wanprestasi karena tidak melakukan prestasinya yang mana seharusnya penjual melakukan prestasinya untuk memberikan sesuatu yaitu objek dari jual belinya. Hal ini juga secara tegas telah menjadi kewajiban utama penjual yaitu melakukan levering sebagaimana dinyatakan dalam Pasal 1474 KUHPerdata (Aan Handriani, 2018, p. 288). Lebih lanjut lagi, Pasal 1235 menyatakan bahwa dalam suatu perikatan untuk memberikan sesuatu terdapat kewajiban debitor untuk menyerahkan kebendaan yang bersangkutan sampai pada levering (Mohamad Kharis Umardani, 2019, p. 17).

Dalam suatu permohonan pernyataan pailit dimana kreditor yang merupakan pembeli mendasarkan utang yang dimiliki debitor yang merupakan penjual atas dasar tidak dilakukannya prestasi untuk memberikan objek jual belinya dalam jangka waktu yang ditentukannya senyatanya telah memenuhi syarat permohonan pernyataan pailit yang ditegaskan dalam Pasal 2 ayat (1) jo. 8 ayat (4) UU KPKPU. Dengan tidak melaksanakan prestasinya untuk memberikan objek jual belinya dalam jangka waktu yang telah ditentukan, maka telah timbul utang yang merupakan kewajiban yang lahir dari perjanjian sebagaimana jika dikaitkan dengan pengertian utang yang termaktub dalam Pasal 1 angka 6 UU KPKPU. Hal ini juga dikarenakan utang yang dimaksud dalam UU KPKPU adalah pengertian utang secara luas yang dianut dalam KUHPerdata.

Kepastian hukum mengenai utang yang telah jatuh waktu dan dapat ditagih berdasarkan prestasi untuk memberikan sesuatu terutama dalam perjanjian jual beli perlulah ditegakkan agar tidak menimbulkan perbedaan penafsiran dan demi melaksanakan penegakan hukum tanpa adanya diskriminasi. Lebih lanjut, untuk menjamin kepastian hukum perlu adanya perumusan antara aturan perundang-undangan dan fakta mengenai adanya utang yang didasarkan atas prestasi seseorang untuk memberikan sesuatu terutama dalam perjanjian jual beli. Ketika secara nyata dalam sidang permohonan pernyataan pailit, fakta yang ada menunjukkan adanya utang yang telah memenuhi syarat Pasal 2 ayat (1) jo. 8 ayat (4) UU KPKPU, maka pada saat itu juga putusan kepailitan harus dijatuhkan kepada debitor.

Dengan demikian diterimanya suatu permohonan pernyataan pailit yang didasarkan kepada perjanjian jual beli terhadap prestasi penjual untuk memberikan suatu objek jual beli senyatanya akan memberikan manfaat bagi banyak pihak serta pembangunan ekonomi yang ada di Indonesia. Lembaga kepailitan pada dasarnya lahir untuk melindungi seluruh kepentingan pihak-pihak yang ada dalam suatu proses kepailitan. Sehingga, seluruh pihak yang ada dalam suatu proses kepailitan dapat dijamin hak-haknya baik kreditor maupun debitor.

\section{Kepastian Hukum Penyelesaian Sengketa Utang Piutang Melalui Lembaga Kepailitan yang Terindikasi Tindak Pidana}

Dalam melakukan penyelesaian sengketa utang piutang dalam dunia bisnis biasanya para pihak akan menempuh jalur non-litigasi terlebih dahulu dengan alasan bahwa melakukan penyelesaian sengketa melalui jalur litigasi akan memakan biaya dan waktu yang cukup banyak. Namun, ketika jalur non-litigasi memang sudah tidak dapat ditempuh lagi, pihak yang memiliki hak atau kreditor biasanya akan menggunakan jalur litigasi yaitu gugatan secara perdata bahkan permohonan kepailitan/PKPU sebagai ultimum remedium (Sutan Remy Sjahdeini, 2009, p. 95). Dan tidak jarang juga dalam beberapa kasus gugatan perdata maupun permohonan kepailitan di saat yang bersamaan juga dilayangkan tuntutan secara pidana untuk memberikan tekanan bagi pihak yang dianggap beriktikad buruk. 
Lembaga kepailitan sebagai salah satu lembaga penyelesaian sengketa utang piutang merupakan bentuk implementasi dari Pasal 1131 dan Pasal 1132 KUHPerdata. Dibentuknya lembaga ini juga merupakan bentuk perwujudan dari pembangunan nasional khususnya dalam dunia bisnis dan lebih khusus lagi dalam dunia sengketa utang piutang sebagaimana yang ditegaskan dalam Pasal 33 ayat (4) UUD 1945.

Untuk melayangkan permohonan pernyataan pailit, kreditor diperlukan untuk membuktikan syarat pailit yang tercantum secara tegas dalam Pasal 2 ayat (1) jo. 8 ayat (4) UU KPKPU yang pada pokoknya mensyaratkan bahwa adanya 2 (dua) atau lebih kreditor dan tidak dibayarnya sedikitnya satu utang yang telah jatuh waktu dan dapat ditagih serta utang harus dibuktikan secara sederhana.

Pemaknaan pembuktian sederhana dalam UU KPKPU ini sendiri masih belum ada batasan dan pengertiannya secara rinci dan tegas sehingga timbul inkonsistensi dalam beberapa putusan pengadilan niaga. Salah satu contoh nyatanya terdapat dalam Putusan Pengadilan Niaga pada Pengadilan Negeri Jakarta Pusat Nomor 56/Pdt.Sus-Pailit/2019/PN Niaga Jkt Pst. yang menyatakan bahwa dikarenakan adanya unsur pidana dalam suatu upaya penyelesaian sengketa utang piutang melalui permohonan pernyataan pailit, maka Majelis Hakim Pengadilan Niaga berpendapat bahwa pembuktian menjadi sederhana. Pendapat ini dipertegas oleh Majelis Hakim Mahkamah Agung dalam Putusan Nomor 831 K/Pdt.Sus-Pailit/2020 bahwa Majelis Hakim pemeriksa judex factie tidak salah dalam menerapkan hukum.

Lebih lanjut lagi terdapat beberapa kasus kepailitan maupun PKPU dan tindak pidana yang berjalan bersamaan seperti kasus PKPU First Travel dan kasus Kepailitan PT Sinar Central Rejeki. Kasus-kasus ini berimplikasi pada adanya benturan kepentingan antara aset yang di sita umum dan di sita pidana oleh penyidik kepolisian maupun kejaksaan, bahkan dalam kasus tindak pidana yang dilakukan First Travel pada amarnya menyatakan aset yang di sita umum yang dijadikan barang bukti di persidangan dirampas untuk negara. Sehingga hal ini menimbulkan pertentangan antara kepentingan sita manakah yang perlu didahulukan. Sehingga hal ini kadang menimbulkan ketidakpastian hukum dalam pengaplikasian alur penyelesaian sengketa.

Suatu kepastian hukum perlu ditegakkan agar meminimalisir terjadinya penafsiran yang berbeda-beda bagi penegak hukum. Kepastian hukum diimplementasikan pada suatu pemberlakuan hukum yang jelas, tetap, konsisten dan konsekuen yang pelaksanaannya tidak dapat dipengaruhi oleh keadaan yang sifatnya subjektif (R. Tony Prayogo, 2016, p. 192). Penegakan suatu kepastian hukum juga perlu diimbangi dengan adanya 2 (dua) tujuan hukum lainnya yaitu kemanfaatan dan keadilan. Ketiga asas ini seharusnya dapat berjalan seimbang dan harmonis. Jangan sampai penegakan kepastian hukum luput terhadap asas kemanfaatan maupun keadilan (Fence M. Wantu, 2007, p. 388).

Keharmonisan 3 (tiga) asas ini diimplementasikan dari suatu putusan hakim karena idealnya putusan hakim jangan sampai menimbulkan masalah-masalah baru di masyarakat pada kemudian hari. Inkonsistensi yang terjadi terhadap suatu penafsiran peraturan perundangundangan yang diimplementasikan melalui suatu putusan pengadilan akan berakibat pada turunnya tingkat kepercayaan masyarakat umum pada penegak keadilan (Tata Wijayanta, 2014, p 217).

Terutama dalam penyelesaian sengketa utang piutang melalui lembaga kepailitan yang terindikasi tindak pidana. Seperti pada permohonan pailit terhadap PT Akumobil yang ditolak berdasarkan Putusan Nomor 56/Pdt.Sus-Pailit/2019/PN Niaga Jkt Pst. karena permohonan pailit terindikasi tindak pidana sehingga pembuktian tidak sederhana. Hal ini tentu menimbulkan ketidakpastian hukum mengenai pemaknaan dari pembuktian sederhana itu sendiri dan tidak mencerminkan asas kemanfaatan yang harusnya diterima para kreditor dalam 
mendapatkan kembali hak perdatanya serta ditolaknya putusan ini menimbulkan ketidakadilan bahwa seakan-akan para kreditor dihalang-halangi untuk mendapatkan keadilannya.

Suatu putusan pengadilan sudah seharusnya menganut asas keadilan yang memberikan hak dan kesempatan yang sama yang seluas-luasnya bagi setiap orang dan mampu untuk mengatur kembali kesenjangan sosial ekonomi yang terjadi sehingga dapat memberikan keuntungan yang bersifat timbal balik bagi setiap orang, baik bagi mereka yang berasal dari kelompok yang beruntung maupun tidak beruntung. Putusan juga seharusnya mencerminkan asas kemanfaatan sehingga dapat mencapai sebanyak mungkin kebaikan, kebahagiaan dan berkurangnya penderitaan.

Dalam permohonan pernyataan pailit yang ditolak akibat adanya perkara pidana yang berjalan bersamaan acapkali masih belum menemui titik jelasnya. Sehingga, pada dasarnya ketika memang dalam mencari solusi dari suatu permasalahan hukum, para penegak hukum perlu untuk kembali lagi ke asas-asas hukum yang menjadi dasar dan tumpuan berpikir dan berpendapat. Asas hukum yang berarti norma dasar yang merupakan pengendapan hukum positif dalam suatu masyarakat harus digunakan untuk menjawab persoalan-persoalan ini.

Lembaga kepailitan sebagai salah satu lembaga penyelesaian sengketa utang piutang dalam dunia bisnis seperti yang ditegaskan dalam Konsideran UU KPKPU haruslah bermanfaat bagi dunia bisnis demi bisa mendongkrak kembali pembangunan ekonomi nasional. Walaupun dalam suatu sengketa bisnis juga seringkali terdapat perkara-perkara pidana di dalamnya, perlu dilihat kembali bahwa sengketa bisnis haruslah diselesaikan secara bisnis pula dan sudah seharusnya pidana menjadi ultimum remedium jangan sampai jalur pidana hanya dijadikan alat untuk melakukan tekanan kepada pihak yang beriktikad buruk.

Gejala untuk mempidanakan masalah penagihan utang piutang yang merupakan ranah hukum privat cukup membahayakan sistem hukum nasional untuk ke depannya. Bahaya jangka pendeknya adalah praktik seperti ini membuka kesempatan untuk penyalahgunaan kekuasaan ataupun pemerasan. Dan bahaya jangka panjangnya adalah akan berpotensi untuk mengaburkan perbedaan antara hukum perdata dan hukum pidana. Untuk itu dalam dunia pembangunan hukum, seharusnya seluruh masyarakat memegang teguh pada batas-batas dan pembedaan antara hukum perdata dan hukum pidana (Mochtar Kusumaatmadja, 2002, p. 194).

Pada dasarnya pengimplementasian asas kepastian dalam untuk menerima permohonan pernyataan pailit yang terindikasi tindak pidana, hakim niaga hanya perlu untuk mempertimbangkan apakah utang yang dimaksud dalam Pasal 2 ayat (1) UU KPKPU dapat terbukti secara sederhana berdasarkan Pasal 8 ayat (4) UU KPKPU. Dengan ada maupun tidak adanya perkara pidana dalam perkara kepailitan tersebut, jika utang memang dapat terbukti maka sudah seharusnya dan sewajarnya hakim menerima permohonan pernyataan pailit tersebut sehingga telah menjunjung tinggi asas kepastian hukum.

Dalam sengketa bisnis pula, dimana banyak pihak yang terdapat di dalamnya sehingga asas kemanfaatan juga dapat diimplementasikan dengan memberikan kebahagiaan sebesarbesarnya bagi para kreditor untuk mendapatkan hak-haknya yang memang seharusnya menjadi miliknya. Dengan diterimanya permohonan pailit tersebut, asas keadilan juga dapat ditegakkan dengan memperhatikan tujuan dari kepailitan itu sendiri yaitu untuk melindungi kepentingan kreditor maupun debitor dari pihak-pihak yang beriktikad buruk (Sutan Remy Sjahdeini, 2009, p. 29-31).

Seperti pada prinsipnya juga, pidana merupakan sebuah ultimum remedium atau senjata pamungkas terakhir sebagai upaya hukum yang paling terakhir dalam penegakan hukum jika dianggap masih terdapat suatu alternatif penyelesaian sengketa lainnya (Sudikno Mertokusumo, 2005, p. 128). Dalam bidang utang piutang, sanksi secara perdata harus ditegakkan terlebih dahulu lalu ketika memang sanksi secara perdata belum cukup untuk tujuan 
meluruskan neraca yang ada di masyarakat, maka pidana seharusnya baru dapat dilaksanakan (Wirjono Prodjodikoro, 1979, p. 17). Hal ini didasarkan pada sifat sanksi pidana yang memiliki sifat yang lebih keras dibandingkan dengan sanksi perdata.

Lebih lanjut lagi, perlu untuk melihat kembali apa sebenarnya tujuan dari pemidanaan itu. Pada kejadian-kejadian seperti ini, tujuan pemidanaan yang paling tepat adalah dengan teori efek jera dan teori rehabilitasi. Dengan menjunjung teori efek jera dan rehabilitasi ini dimaksudkan kepada pelaku kejahatan agar tidak mengulangi kembali perbuatan yang dilakukannya serta agar pelaku kejahtan dapat diperbaiki ke arah yang lebih baik lagi sehingga ketika dirinya kembali ke masyarakat, ia dapat diterima kembali di kehidupan bermasyarakat. Sanksi pidana harus dimaknai sebagai obat (Eddy O. S. Hiariej, 2006, p. 16).

Berdasarkan tujuan pemidanaan dan dihubungkan dengan mekanisme penyelesaian sengketa utang piutang yang terindikasi tindak pidana, maka dikarenakan sengketa ini termasuk ke dalam ruang lingkup bisnis, penyelesaiannya haruslah diselesaikan secara bisnis terlebih dahulu dan pidana harus bertindak sebagai ultimum remedium untuk memberikan efek jera dan melakukan rehabilitasi kepada pelaku tindak pidana agar ia tidak melakukan perbuatannya lagi di kemudian hari dan pada akhirnya dirinya dapat diterima kembali di kehidupan bermasyarakat. Dengan melakukan pemidanaan di awal sebelum menyelesaikannya melalui cara bisnis yaitu kepailitan/PKPU, maka akan menimbulkan ketidakpastian hukum mengenai pelunasan hak-hak perdata yang harusnya diterima oleh pihak-pihak yang memiliki hak/kreditor.

Terlebih lagi ketika ditemukannya perkara kepailitan yang dijalankan bersamaan dengan perkara pidana. Hal ini akan menimbulkan polemik di kemudian hari mengenai penyitaan yang terjadi. Di satu sisi kepailitan memiliki akibat hukum untuk melakukan sita umum terhadap seluruh harta kekayaan debitor pailit dan di satu sisi perkara pidana memiliki kepentingan untuk melakukan sita untuk proses pembuktian di penyidikan maupun di persidangan, bahkan barang bukti yang didapatkan dari suatu tindak pidana dapat dirampas untuk negara.

Seperti yang terjadi dalam Kasus First Travel, dimana uang hasil tindak pidana yang didapatkan oleh First Travel yang mana uang tersebut merupakan uang dari para calon jamaah umroh dirampas untuk negara. Dengan adanya kasus ini mencerminkan bahwa adanya hak-hak dari kreditor First Travel tidak mendapatkan kembali apa yang seharusnya menjadi haknya. Dan di saat yang bersamaan First travel juga sedang menjalani proses PKPU dimana barang bukti yang dirampas untuk negara tersebut merupakan harta kekayaan First Travel yang akan digunakan untuk pemenuhan hak-hak dari kreditornya. Padahal Pasal 46 ayat (1) KUHAP juga telah menyatakan benda yang disita dikembalikan kepada orang yang paling berhak. Penentuan orang yang paling berhak disini adalah mutlak pada pemilik atau korban yang memiliki benda tersebut, sehingga yang dianggap paling berhak untuk menerima barang sitaan adalah pemilik yang sebenarnya yaitu bukan negara, melainkan para calon jamaah umroh dari First Travel.

Kemudian, mengenai benturan yang terjadi antara sita umum dan sita pidana sampai saat ini juga belum menemui titik tengah. Benturan kepentingan yang terjadi dikarenakan terdapat 2 (dua) pengaturan mengenai sita yang menyatakan untuk menghapuskan sita lainnya dalam 2 (dua) peraturan perundang-undangan yang berbeda dan memiliki hirearki peraturan perundang-undangan yang sejajar, yaitu pengaturan sita pidana dalam Pasal 39 ayat (2) KUHAP dan pengaturan sita umum dalam Pasal 31 ayat (1) jo. ayat (2) UU KPKPU.

Pasal 39 ayat (2) KUHAP pada pokoknya menyatakan bahwa benda yang berada dalam sitaan perdata juga disita untuk kepentingan penyidikan, penuntutan dan mengadili perkara pidana. Sedangkan Pasal 31 ayat (1) jo. ayat (2) UU KPKPU pada pokoknya menyatakan semenjak putusan pernyataan pailit diucapkan maka segala bentuk penetapan pelaksanaan 
pengadilan harus dihentikan seketika dan seluruh penyitaan yang dilakukan menjadi hapus dan kalau perlu Hakim Pengawas harus memerintahkan pencoretannya.

Untuk memecahkan persoalan yang ada terhadap terdapatnya 2 (dua) ketentuan yang saling berbenturan dalam 2 (dua) rezim hukum yang berbeda, maka harus ditinjau kembali dari asas-asas hukum umum sebagai pikiran dasar yang bersifat umum yang menjadi fundamental dari suatu kaidah. Asas hukum mengandung nilai-nilai dan tuntutan tuntutan etis, merupakan jembatan antara peraturanperaturan hukum dengan cita-cita sosial dan pandangan etis masyarakatnya. Solusi dari permasalahan ini adalah dengan ditegakkannya asas keadilan, asas kemanfaatan dan asas kepastian hukum sebagai tujuan hukum sebagaimana yang dinyatakan oleh Gustav Radbruch.

Asas keadilan dalam lembaga kepailitan adalah dengan diberlakukannya sita umum terhadap seluruh harta kekayaan debitor pailit untuk melindungi harta debitor pailit dari pihakpihak yang beriktikad buruk, baik itu debitornya sendiri maupun kreditor. Tujuan dari adanya sita umum ini adalah untuk menegakkan keadilan bagi kreditor untuk mendapatkan kembali hak-haknya yang sudah semestinya menjadi miliknya. Diterapkannya sita pidana dalam penyelesaian sengketa utang piutang melalui lembaga kepailitan yang terindikasi pidana akan menimbulkan ketidakadilan di kemudian hari jika memang sita pidana yang terjadi akan mengakibatkan harta debitor tersebut dirampas untuk negara dan pemenuhan hak-hak dari kreditor akan terhambat. Lebih lanjut lagi, harta debitor yang dibutuhkan untuk kepentingan penyidikan/penuntutan biasanya akan memakan waktu yang cukup lama dan berpotensi untuk menurunkan nilai dari harta tersebut sehingga berakibat nilai dari boedl pailit akan turun juga yang mana akan merugikan kreditor konkuren dalam pemenuhan hak-haknya.

Asas kemanfaatan menjunjung tinggi kebahagiaan yang harusnya diterima masyarakat yang seluas-luasnya. Dengan diberlakukannya sita umum di atas sita pidana, kreditor akan dijamin kepastian pelunasan piutang-piutangnya sehingga akan menciptakan kebahagiaan yang seluas-luasnya bagi seluruh kreditor, dimana dalam perkara kepailitan pada dasarnya terdapat kreditor yang jumlahnya cukup banyak. Ketika sita pidana didahulukan, manfaat yang diterima para kreditor belum tentu dapat diterima dikarenakan kepastian dari harta debitor yang digunakan sebagai barang bukti dalam penyidikan maupun penuntutan kepastiannya harus menunggu amar putusan pidana dibacakan oleh hakim pemeriksa perkara pidana tersebut. Walaupun memang kepentingan publik harus didahulukan dibandingkan kepentingan privat, namun memperhatikan perkara kepailitan yang juga memiliki banyak kreditor maka asas kemanfaatan juga harus dijunjung tinggi. Potensi adanya barang bukti yang dirampas untuk negara tidak menciptakan manfaat yang luas bagi masyarakat umum seperti yang ada pada kasus First Travel.

Asas kepastian hukum ditegakkan dengan adanya penerapan hukum yang konkret, tetap dan konsisten. Sita umum yang merupakan suatu akibat hukum dari produk hukum putusan pengadilan dan sita pidana yang merupakan suatu akibat hukum dari produk hukum penetapan pengadilan memperlihatkan seharusnya telah terdapat jawaban dari semua persoalan yang terjadi sebagaimana yang dinyatakan dalam Pasal 31 ayat (1) UU KPKPU bahwa semenjak putusan pernyataan pailit diucapkan maka segala bentuk penetapan pengadilan haruslah hapus. Karena pada dasarnya suatu putusan pengadilan hanya dapat dibatalkan dengan suatu putusan pengadilan juga (M. Hadi Subhan, 2009, p. 135). Jika seluruh penegak hukum memperhatikan ketentuan Pasal 31 ayat (1) UU KPKPU ini, kepastian hukum dapat ditegakkan tanpa memandang siapa pihak yang ada dibaliknya. Namun, perlu ditegaskan kembali bahwa ketentuan ini seharusnya hanya dapat diberlakukan pada sengketa utang piutang dalam dunia bisnis yang terindikasi tindak pidana. 
Namun, di sisi lain Kurator sebagai lembaga yang diberikan kewenangan untuk mengurus harta pailit juga harus memperhatikan kepentingan penyidik ataupun kejaksaan dalam hal adanya kepentingan penyidikan maupun penuntutan. Hal ini dikarenakan suatu barang bukti dalam perkara pidana memiliki fungsi yang sangat penting untuk kepentingan pembuktian dalam meyakinkan hakim mencari runtutan-runtutan peristiwa dan perbuatan yang dilakukan oleh terdakwa. Sehingga, harus ada jalan tengah yang perlu diambil oleh Kurator dan penyidik maupun kejaksaan dalam terjadinya pertentangan sita yang terjadi ini.

Dengan demikian terhadap suatu penyelesaian sengketa utang piutang melalui lembaga kepailitan yang terindikasi tindak pidana, perlu ditinjau mengenai apakah perkara ini merupakan perkara bisnis atau bukan. Perkara bisnis haruslah diselesaikan secara bisnis (perdata) terlebih dahulu dan sanksi pidana harus ditempatkan sebagai ultimum remedium atau senjata terakhir agar di kemudian hari tidak ada lagi perkara kepailitan dan pidana yang berjalan bersamaan bahkan jika memang masih akan terjadi, benturan kepentingan antara sita umum dan sita pidana sudah seharusnya menemukan jalan keluarnya dengan menjunjung tinggi asas keadilan, kemanfaatan dan kepastian hukum sebagai tujuan hukum itu sendiri.

\section{KESIMPULAN DAN SARAN}

\section{Kesimpulan}

1. Utang yang lahir berdasarkan prestasi debitor untuk memberikan sesuatu dalam perjanjian jual beli dapat diklasifikasikan sebagai utang yang disyaratkan dalam Pasal 2 ayat (1) UU KPKPU, sehingga untuk menjunjung tinggi kepastian hukum jika secara mutlak dalam sidang permohonan pernyataan pailit fakta telah menunjukkan adanya syarat utang yang telah terpenuhi maka permohonan pernyataan pailit haruslah diterima.

2. Penyelesaian sengketa utang piutang yang terindikasi tindak pidana dalam dunia bisnis harus diselesaikan secara bisnis terlebih dahulu, khususnya secara perdata ataupun kepailitan/PKPU. Sanksi pidana harus dimaknai sebagai ultimum remedium dalam penyelesaian sengketa. Asas keadilan, kemanfaatan dan kepastian hukum sebagai tujuan dari hukum perlu ditinjau lebih jauh untuk menentukan jalur manakah yang dapat melahirkan lebih banyak keadilan dan manfaat demi kepastian hukum yang konsisten. Terlebih lagi akibat yang akan ditimbulkan adalah benturan kepentingan antara sita pidana dan sita umum, namun kembali lagi bahwa persoalan ini dapat ditemukan solusinya dengan meninjau kembali asas keadilan, kemanfaatan serta kepastian hukum.

\section{Saran}

1. Ketidakpastian hukum mengenai pengertian utang yang telah jatuh waktu dan dapat ditagih serta pembuktian sederhana yang termaktub dalam Pasal 2 ayat (1) jo. 8 ayat (4) UU KPKPU memerlukan suatu produk hukum baru yang mempertegas pengertian serta pengimplementasian dari utang yang telah jatuh waktu dan dapat ditagih serta pembuktian sederhana agar tidak menimbulkan perbedaan penafsiran serta inkonsistensi yang terjadi pada putusan yang dikeluarkan oleh pengadilan niaga. Produk hukum yang dimaksud dapat berupa Peraturan Pemerintah untuk mempertegas pelaksanaan ketentuan di atas atau dapat juga melakukan revisi terhadap UU KPKPU, atau bahkan mengeluarkan peraturan perundang-undangan baru di bidang kepailitan dan PKPU. 
2. Dalam hal munculnya sengketa utang piutang yang terindikasi tindak pidana dalam dunia bisnis, pada pokoknya harus diselesaikan secara bisnis terlebih dahulu khususnya kepailitan/pkpu untuk menjamin pemenuhan hak-hak dari para kreditor. Baru setelahnya, berdasarkan prinsip ultimum remedium negara sebagai pemberi sanksi pidana dapat menegakkan ketentuan pidana terhadap debitor yang terindikasi tindak pidana ini.

3. Dengan adanya kekosongan hukum yang terjadi terhadap benturan kepentingan antara sita umum kepailitan dan sita pidana, penulis memiliki beberapa saran sebagai berikut:

1) Sita umum sebagai akibat hukum dari Putusan Pailit/PKPU dan sita pidana sebagai akibat hukum dari Penetapan Pengadilan, maka keduanya merupakan produk hukum yang dibawahi langsung oleh Mahkamah Agung sehingga penulis menyarankan agar Mahkamah Agung untuk mengeluarkan Surat Edaran Mahkamah Agung yang ditujukan kepada para hakim-hakim yang merupakan pejabat di lingkungan badan peradilan yang pada pokoknya mempertegas kedudukan diantara sita umum dan sita pidana sebagai akibat hukum dari suatu produk hukum yang dikeluarkan oleh instansi yang dibawahi oleh Mahkamah Agung.

2) Asosiasi Kurator dan Pengurus Indonesia (“AKPI") maupun Himpunan Kurator dan Pengurus Indonesia ("HKPI") perlu untuk membuat suatu nota kesepahaman dengan Kepolisian Republik Indonesia dan Kejaksaan Republik Indonesia mengenai boedl pailit yang dibutuhkan untuk kepentingan penyidikan, penuntutan maupun pembuktian. Nota kesepahaman yang dimaksud haruslah termuat klausul mengenai kepastian hukum dari boedl pailit yang dijadikan barang bukti tersebut. Kepolisian Republik Indonesia dan Kejaksaan Republik Indonesia harus dapat memastikan bahwa barang bukti tersebut dapat dikembalikan kepada yang berhak yaitu para kreditor dalam perkara kepailitan untuk menjunjung tinggi asas keadilan, kemanfaatan maupun kepastian hukum.

3) Penyidik Polri dan Kejaksaan dalam melakukan penyitaan barang bukti yang termasuk ke dalam boedl pailit tidak serta merta mengambil penguasaan dari benda tersebut, sehingga penguasaannya tetap pada pihak yang pertama kali melakukan penyitaan, yaitu kurator dan hal ini seharusnya juga berlaku kebalikannya.

\section{DAFTAR PUSTAKA}

\section{Buku}

Eddy O. S. Hiariej, Prinsip-Prinsip Hukum Pidana, Yogyakarta: Cahaya Atma Pustaka, 2006.

H. M. N. Purwosutjipto, Pengertian dan Pokok-Pokok Hukum Dagang Indonesia, Jakarta: Djambatan. 1979.

J. Satrio, Wanprestasi menurut KUHPerdata, Doktrin dan Yurisprudensi, Bandung: PT Citra Aditya Bakti, 2014.

M. Hadi Shubhan, Hukum Kepailitan: Prinsip, Norma dan Praktik di Pengadilan, Jakarta: Kencana, 2009.

Man S. Sastrawidjadja, Hukum Kepailitan dan Penundaan Kewajiban Pembayaran Utang, Bandung: Alumni, 2006.

Mariam Darus Badrulzaman, KUH Perdata Buku III: Hukum Perikatan dengan Penjelasan, Bandung: Alumni, 2011.

Mochtar Kusumaatmadja, Konsep-Konsep Hukum dalam Pembangunan, Bandung: Alumni, 2002. 
Soerjono Soekanto dan Sri Mamudji, Penelitian Hukum Normatif, Jakarta: PT Raja Grafindo Persada, 2003.

Subekti, Aneka Perjanjian, Bandung: PT Citra Aditya Bakti, 1995.

Subekti, Pokok-Pokok Hukum Perdata, Jakarta: PT Intermasa, 1985.

Sudikno Mertokususmo, Mengenal Hukum Suatu Pengantar, Yogyakarta: Liberty, 2005.

Sutan Remy Sjahdeini, Hukum Kepailitan: Memahami Undang-Undang Nomor 37 Tahun 2004 tentang Kepailitan, Jakarta: Pustaka Utama Grafiti, 2009.

Wirjono Prodjodikoro, Asas-Asas Hukum Pidana di Indonesia, Bandung: Sumur, 1979.

\section{Jurnal Hukum}

Aan Handriani, "Keabsahan Perjanjian Jual Beli Secara Tidak Tertulis Berdasarkan Hukum Perdata", Rechtsregel: Jurnal Ilmu Hukum, Vol. 1, No. 2, Desember 2018.

Arif Firmansyah, "Penafsiran Pasal 33 UUD 1945 dalam Membangun Perekonomian di Indonesia", Jurnal Syiah Hukum, Vol. 13 No. 1, Maret 2012.

Elli Ruslina, "Makna Pasal 33 Undang-Undang Dasar 1945 Dalam Pembangunan Hukum Ekonomi Indonesia", Jurnal Konstitusi, Vol. 9, No. 1, Maret 2012.

Fence M. Wantu, “Antinomi dalam Pengakan Hukum oleh Hakim” Jurnal Berkala Mimbar Hukum, Vol. 19, No. 3, Oktober 2007.

Mohamad Kharis Umardani, "Jual Beli Berdasarkan Kitab Undang-Undang Hukum Perdata dan Hukum Islam (Al Qur'an-Hadist) Secara Tidak Tunai”, Journal of Islamic Law Studies, Sharia Journal, Vol. 9, No. 2, Mei 2019.

R. Tony Prayogo, "Penerapan Asas Kepastian Hukum Dalam Peraturan Mahkamah Agung Nomor 1 Tahun 2011 Tentang Hak Uji Materiil Dan Dalam Peraturan Mahkamah Konstitusi Nomor 06/PMK/2005 Tentang Pedoman Beracara Dalam Pengujian Undang-Undang”, Jurnal Legislasi, Vol. 13 No. 2, Juni 2016.

Sugirhot Marbun, Mahmud Mulyadi, Suhaidi dan Mahmul Siregar, "Perbedaan Antara Wanprestasi dan Delik Penipuan dalam Hubungan Perjanjian”, USU Law Journal, Vol. 3, No. 2, Agustus 2015.

Tata Wijayanta, "Asas Kepastian Hukum, Keadilan dan Kemanfaatan dalam Kaitannya dengan Putusan Kepailitan Pengadilan Niaga", Jurnal Dinamika Hukum, Vol. 14, No. 2, Mei 2014.

\section{Peraturan Perundang-Undangan}

Kitab Undang-Undang Hukum Acara Pidana

Kitab Undang-Undang Hukum Perdata

Kitab Undang-Undang Hukum Pidana

Undang-Undang Dasar Republik Indonesia Tahun 1945 Hasil Amandemen

Undang-Undang Nomor 37 Tahun 2004 tentang Kepailitan dan Penundaan Kewajiban Pembayaran Utang 